\title{
Vulnerability by people: lesson learned from vulnerable group in kampong aur medan in facing floods
}

\author{
Luh Kitty Katherina ${ }^{1, *}$, Lengga Pradipta ${ }^{1}$ \\ ${ }^{1}$ Research Center for Population, Indonesian Institute of Sciences (LIPI), Indonesia
}

\begin{abstract}
The flooding in Medan due to heavy rainfall area has become a daily problem to the community who lives in the riverbanks. It has been happening since many decades ago, but they are still there. Information on the vulnerability to natural hazards on a local level may help decision makers, stakeholders, and others to make better decisions regarding an effective disaster management. This study uses a qualitative approach to measure the level of vulnerability of communities in facing floods. The study identified how the communities perceive their exposure to the hazard, their sensitivity and their adaptive capacity. This study found the community already accept floods as a part of their life although the floods cause many losses. The experience in facing floods, strong social neighbourhood and strong local leadership are the capitals of the communities to survive. So vulnerability assessment at the community level should be constructed based on the perception and meaning of the community.
\end{abstract}

\section{Introduction}

Studies on vulnerability, particularly due to floods, have been largely undertaken primarily by governments, academics and non-government organizations (NGOs). Most of the vulnerability studies based on only secondary data. Often the policies taken are not in accordance with the needs of the community because less involvement of the community. The government has already made various efforts to reduce negative impacts of floods but not people's vulnerability [1].

The assessment of vulnerability becomes important, especially since the focus shifted from a technical hazard perspective to a more social centered one [1]. Vulnerability, defined as the losses potential, is an essential concept in hazards research. Vulnerability is also the focus of the development of hazard mitigation strategies at the local, national and international level [2]. The vulnerability is a function of the exposure (who or what is at risk) and sensitivity of a system (the degree to which people and places can be harmed) $[3,2]$. The IPCC definition [4] of vulnerability is a degree to which a system susceptible and incapability to cope with adverse effects (of climate change). In this paper, vulnerability is the degree to which a community, a household or a person is "likely to experience harm due to exposure to a hazard, either an exogenous perturbation or an endogenous stress or stressor" [5].

In the last two decades, flood was recorded as the most frequent disaster happened in Indonesia, including its big cities, like Medan City especially in the rainy season. There are 7 (seven) sub-districts regularly experience floods every year in Medan City with the various characteristics of the location and the victims.
The poor is the most vulnerable group to the disaster [6]. Then it is assumed that the slum dwellers in the city are the most vulnerable to the disaster [7].

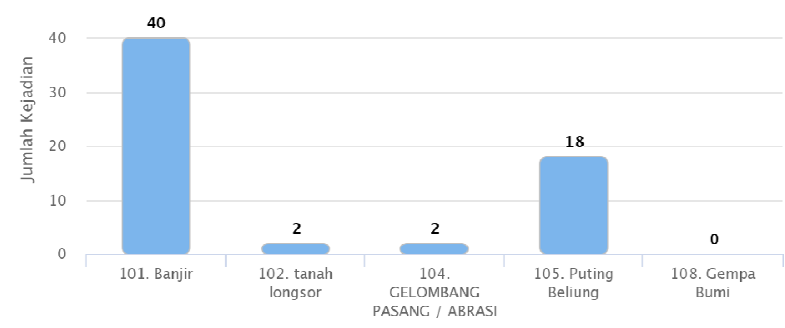

Fig. 1. Disaster in Medan City 2000-2017

Source: DIBI, BNPB (accessed 31 March 2018)

In many cases, the densely populated urban areas or urban slums, high vulnerability and high risk do not reduce the population, even increase in some locations $[7,8]$. The ability of slum dwellers to manage the floods for decades becomes an interesting research topic. Their knowledge and capabilities over the time can be a good idea to reduce vulnerability in the other similar areas. Their vulnerability determination and actions are the unique local factors and recognized as key factors in building disaster risk management capacity at the local level [8].

This study uses a qualitative approach to measure the level of vulnerability of communities in facing floods. The individual interviews and focus groups discussions are the tools to learn about the factors establishing the vulnerability from the local people. This study takes the study case in Kampong Aur Kota Medan as the representation of urban slum and dense community in the big city. This Kampong is located in the center of

Corresponding author: kittykatherina@gmail.com 
Medan City, on the edge of the Deli River, very often flooded. The residents in the area still survive even though there are three to four times a month must deal with floods. The inhabitants here accept the risk of flood as trade-offs in contrary to the opportunities their residential location.

\section{Material and method}

The concept of vulnerability is still a lot of debate, especially in the context of climate change and natural hazards, resulting in various definitions and approaches $[3,9,10]$. This study refers definition of vulnerability combine with human-environment systems [5]. It consider the complexity of vulnerability consists of multiple interacting social, economic and environmental factors operating on different spatial scales. The concept of vulnerability comprises three fundamental dimensions, namely exposure, susceptibility and resilience/adaptive capacity $[3,11]$.

This study consider the exposure, sensitivity and adaptive capacity as variables of vulnerability, which measured by the experiences of villagers. This approach referring to the previous study [12]. Qualitative methods reconstruct how people experience and make sense of their lives [13]. Thus, they try to take up the specific perspectives of the interviewees. In comparison, the quantitative approaches with weighted indicators, these individual perspectives provide supplemental and deeper information about distinct perceptions and factors determining vulnerability [1].

The validity of the information obtained if the results of in-depth interviews and FGDs indicate consistency. The content analysis to classify the causes and effects of floods, which is the value of the exposure and the resulting impact to the sensitivity.

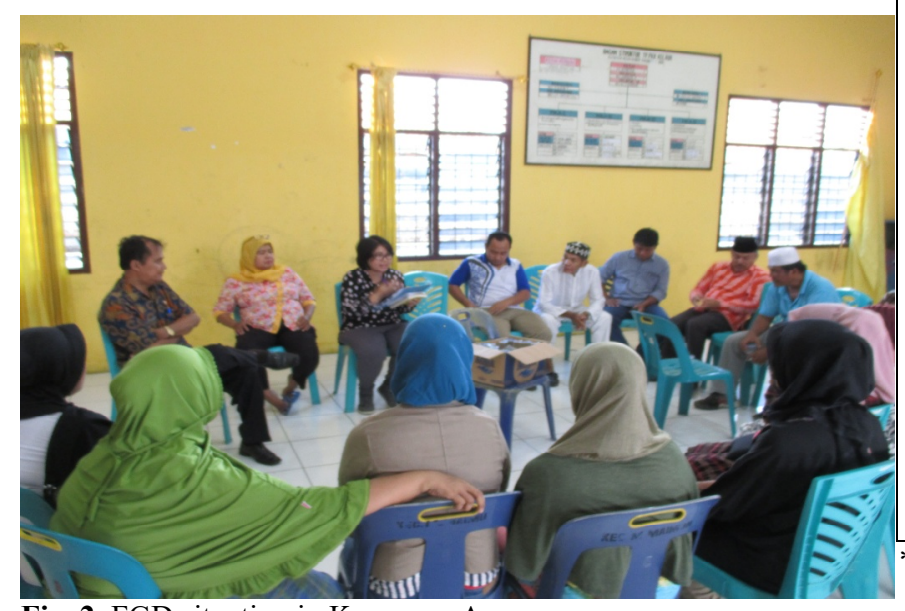

Fig. 2. FGD situation in Kampong Aur

*courtesy: Human Ecology team LIPI, 2017

\section{Results and discussion}

\subsection{Kampong and flood risk}

Decentralization, to some extent, has drastically contributed to rural and urban development transformation and, including the governance system. In this phase, there is a vivid situation which showed about urbanization process, it's triggered by people who migrated from rural to urban area. They mobilized because there are better opportunities in cities [14].

Thus, the terminology of Kampong itself can be defined as a dwelling place where migrants inhabit or traditional settlements of local people. Since the majority of people come from low-income level, they usually have limited infrastructure and services, such as lack of proper clean water and sanitation supply, electricity connection and also solid-waste disposal. Again, [15] implied that the concept of Kampong in an urban area is categorized as a slum, and it has to be considered not only as an area, but also as a cultural expression. Lowquality housing standard and limited infrastructure and are the symbol of urban poverty. Furthermore, [16] added that Kampong in urban areas are densely populated, because urbanization has occurred around them. Kampong mostly located in strategic parts of the city, where its near government centers, markets, and other public facilities. Kampong which attached city could be classified either by location or by its type of development.

Table 1. Classification of Kampong, by location and type of development

\begin{tabular}{|l|l|}
\hline \multicolumn{2}{|c|}{ Classification of Kampong } \\
\hline \multicolumn{1}{|c|}{ By location } & \multicolumn{1}{|c|}{ By type of development } \\
\hline - Open Kampongs: have & - Traditional Kampong: mostly \\
direct access to & old and built by the earliest \\
principal streets & inhabitants of a city \\
- Semi-open Kampongs: & - Built by city government \\
in commercial areas, & during the colonial period: in \\
but "closed" & strategic locations to provide \\
(surrounded) by public & cheap labor to wealthy areas \\
buildings & - Regularized: originally \\
- Closed Kampongs: in & squatters on public land, \\
inner-city areas, but & primarily before the enactment \\
away from main streets & of the Agrarian Law no. \\
- Fringe Kampongs: in & 5/1960 \\
the periphery of built- & - Reclaimed and regularized: \\
up areas; usually with & very similar to the previous \\
high population growth & one. But on reclaimed land. \\
- "Rural" Kampongs: & Primarily coastal areas, \\
still within the & cemeteries, or marshlands. \\
administrative & - Marginal Kampongs: do not \\
boundaries of cities, & conform to land-use plans, and \\
bult with a strong rural & cannot be regularized due to \\
atmosphere; easy & problems of land rights and/or \\
access to urban & marginal land, along the main \\
facilities & storm drains or railroad tracks \\
\hline *apted from[16] &
\end{tabular}

Flood makes bigger economic losses and environmental damage than decades ago [15]. Medan, a city with more than 2 million of population and the fourth most populated city in Indonesia regularly attacked by flood [18]. This city has big rivers; Deli River, Babura River and others, which might cause flood every year. The Medan most crucial thing is an overexploitation of natural resources in an upstream area [19]. 
According to the Regional Agency of Disaster Management (BPBD) Medan, the big floods happened 5 (five) times in urban area [20]. The last flood happened on September 27, 2017, which caused the water debit in the Deli River up to $80 \mathrm{~cm}$ and shanked 60 houses. The detail of flood disaster in Medan can be seen in Table 2 .

Table 2. Flood in Medan during 2000 - 2016

\begin{tabular}{|l|l|l|}
\hline Year & \multicolumn{1}{|c|}{ Disaster } & \multicolumn{1}{|c|}{ Losses/damages/victims } \\
\hline 2001 & Flash flood & No data*) \\
\hline 2003 & Flash flood & 154 people swept away \\
\hline 2009 & Flash flood & 25 people died \\
\hline 2011 & Flash flood & $70 \%$ of residential soaked \\
\hline 2012 & $\begin{array}{l}\text { Flood caused by river } \\
\text { flows }\end{array}$ & $\begin{array}{l}5 \text { villages soaked } \\
11 \text { houses swept away } \\
40 \text { houses were heavily } \\
\text { damaged } \\
740 \text { HH displaced }\end{array}$ \\
\hline 2014 & $\begin{array}{l}\text { Flood caused by river } \\
\text { flows }\end{array}$ & 12 sub-district sunk \\
\hline 2016 & $\begin{array}{l}\text { Flood caused by river } \\
\text { flows }\end{array}$ & 4 sub-districts sunk \\
\hline 2017 & $\begin{array}{l}\text { Flood caused by river } \\
\text { flows }\end{array}$ & 60 houses sunk \\
\hline
\end{tabular}

*data is collected from many sources

One of the Kampong with densely populated and located in the river banks of Deli River is Kampong Aur. The community in Kampong Aur ${ }^{\mathrm{a}}$ has experienced flood many times. From a social perspective, the community in Kampong Aur has unique socio-cultural and historical conditions. Malay and Minangkabau culture has been driven in Kampong Aur since the Sultan of Deli. It shapes their social character for being 'united' and it will be impacted by their capacity to cope with environmental changes and floods [21]

\subsection{The role of kampong in adapting to flood}

The informality of Kampong is embedded because of the urbanization process which occurred since 1970s. Even though informality in urban context do not have a direct correlation with marginality, but at one side, the sense of 'informality' can be seen in many sectors of Kampong in an urban area, such as; informal settlement, informal job and informal market which always associated with urban poor communities.

The poor condition and also the risk situation become the major that led Kampong to be unsafe. Therefore, Kampong has actually had the important role for urban poor community, because it is their first protector when disaster attacked. Due to that reason, urban poor people who reside in Kampong have to adapt to disaster, either as an individual or even as a community [22].

The poors are the most vulnerable groups when the disaster happened [23]. In addition they have limited resources to survive during pre, emergency or even during post-disaster periods which become the biggest

\footnotetext{
${ }^{\text {a }}$ Kampong Aur is a densely populated residence located in Medan Maimun Sub-district, Medan. This area is located in the Deli river-banks
}

obstacle for the urban poor community. In Kampong Aur, people are getting used to the flood and they can manage the risk by traditional or local practices.

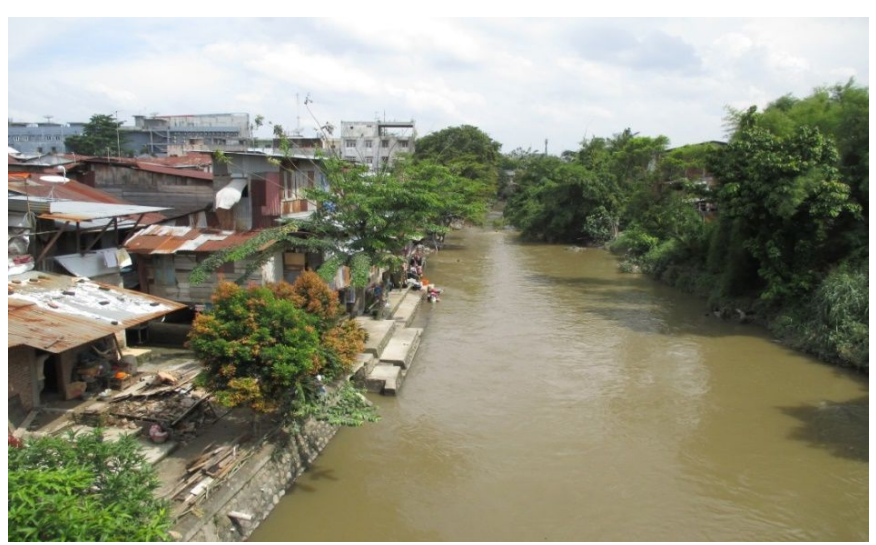

Fig 3. Kampong Aur in Medan

*courtesy: Human Ecology team LIPI, 2017

\subsection{Local knowledge in measuring vulnerability of flood in kampong aur}

The experience of regular flooding makes the people to survive or spontaneous capacity in the face of severe floods. Floods seem to be accepted as part of their lives, considered no big deal anymore. In some decades, their knowledge in the facing floods is transferred from generation to generation. There is inherited knowledge related to the physical condition of buildings that begin transforming from one floor to two floors $(70 \%$ of houses have 2 floors).

\subsubsection{Kampong's exposure}

Exposure is the nature and degree to which a system experiences environmental or socio-political stress [3]. The characteristics of these stresses include their magnitude, frequency, duration and areal extent of the hazard [24]. Local knowledge of Kampong Aur residents is recognized for their ability to understand the exposure of their residential location. Floods that occur in their area come from the upstream during the rain. When the river water is already cloudy, a lot of garbage on the river and the increase water flow are the sign that the great flood is coming soon. The condition of this river is usually first recognized by residents whose dwellings directly adjacent to the river. They then informed the surrounding neighbors, and the information then spread throughout the people in Kampong.

Although Kampong Aur is often shanked, the flooding characteristics in this area are rapidly declining. Floods generally rise in the night until early morning (22:00 - 03:00 in the morning) then began to move away in the morning and in the afternoon people can clean up again. Not only cleaning their homes, residents also have to work hard to clean up the environment so that daily life can run again. 


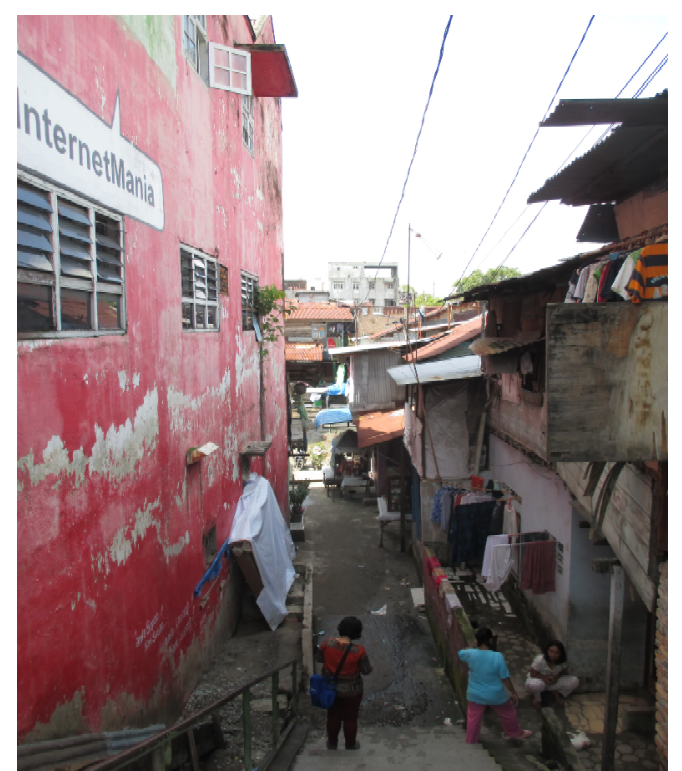

Fig. 4. Entrance to Kampong Aur

*courtesy: Human Ecology team LIPI, 2017

\subsubsection{Kampong's sensitivity}

Sensitivity is the degree to which people and places can be harmed [3, 2] Kampong Aur residents are aware of their own conditions contributing to their level of vulnerability. Socio-economic conditions of society also greatly affect the vulnerability of the population. The limited resources they have make them limited in carrying out sustainable adaptation measures. Since poor conditions make them do not have many valuables property to be protected so they tend to think the flood is not a high threat to their assets.

On the other hand, the high relationship (Kampong Aur is still homogeneous with $90 \%$ of its inhabitants are Minang people) forming strong social bond that play a major role in the facing floods. Local leadership, as well as the presence of youth groups are ready to help evacuation in case of flood. That is why casualties are very rare in the Kampong.

\subsubsection{Kampong's adaptive capacity}

Kampong Aur peoples have adapted independently based on the experience of flooding many times over the decades. Most of the two-floor buildings where generally have the ground floor with no valuables things that may be damaged by flooding.

There are no long-term adaptation activities to reduce the impact of flooding. Besides due to unsecured land occupancy, the limited economic conditions and floods that come almost once a week keep the residents' time and energy running out for cleaning, without having to think about long-term solutions to the reduction of flood impacts and losses. Residents tend to let the floods come and then clean the house.

\section{Conclusions}

There are three interesting findings from the Kampong Aur as a case study. First, the people already considers that flooding is a routine regular occurrence, part of their lives. However, they are also aware that the floods bring many losses both economically, physically and time. Second, their experience of flooding makes them have a "own system" that is already running well when the flood comes, starting from the preparedness, early warning, response and recovery. Thirdly, local leaders play a major role in dealing with floods. The local leader is not only the head of the neighborhood but also the social groups such as the youth group. Youth groups spontaneously move to help to evacuate goods or people in case of flood. This strong social bond becomes a power in facing of floods.

We would like to thank the Research Center for Population LIPI, especially Human Ecology Research Cluster for permits to publish this research in Ikatan Ahli Bencana Indonesia conference.

\section{References}

1. Massman, F and Wehrhahn, R. Qualitative social vulnerability assessments to natural hazards: examples from coastal Thailand. Journal of Integrated Coastal Zone Management 14(1):3-13.

2. Cutter, S.L., 1996. Vulnerability to environmental hazards. Progress in Human Geography 20, 529539.

3. Adger, W. N. (2006) - Vulnerability. Global Environmental Change, 16(3):268-281. DOI: 10.1016/j.gloenvcha.2006.02.006.

4. McCarthy, J.J., Canziani, O.F., Leary, N.A., Dokken, D.J., White, K.S. (Eds.), 2001. Climate Change 2001: Impacts, Adaptation and Vulnerability. Cambridge University Press, Cambridge.

5. Turner, B.L.; Kasperson, R.E.; Matson, P.A.; McCarthy, J.J.; Corell, R.W.; Christensen, L.; Eckley, N.; Kasperson, J.X.; Luers, A.; Martello, M.L.; Polsky, C.; Pulsipher, A.; Schiller, A. (2003) - A framework for vulnerability analysis in sustainability science. Proceedings of the National Academy of Sciences of the United States of America, 100(14):8074-8079. DOI: 10.1073/pnas.1231335100.

6. Adger, W.N., 2003. Social capital, collective action and adaptation to climate change. Economic Geography 79, 387-404.

7. Wilhelm, M. Approaching Disaster Vulnerability in a Megacity: Community Resilience to Flooding in two Kampungs in Jakarta. Dissertation. University of Passau. 2011.

8. Simarmata, H.A., 2016. Locally Embedded Adaptation Planning, A trilogy of adaptive knowledge of flood-affected people in Jakarta. 
Rheinischen, Friedrich-Wilhelms-Universität, Bonn.

9. Bohle, H.-G.; Glade, T. (2007) Vulnerabilitätskonzepte in Sozial- und Naturwissenschaften. In: C. Felgentreff \& T. Glade (eds.), Naturrisiken und Sozialkatastrophen, pp.99119, Elsevier/Spektrum, Heidelberg, Germany. ISBN: 978-3827415714.

10. Cutter, S.L.; Boruff, B.J.; Shirley, W.L. (2003) Social Vulnerability to Environmental Hazards. Social Science Quarterly, 84(2):242-261. DOI: 10.1111/1540-6237.8402002

11. Birkmann, J. 2007. Risk and Vulnerability Indicators at Different Scales: Applicability, Usefulness and Policy Implications. Environmental Hazards Journal. Volume 7, Issue 1, 2007. Pages $20-31$

12. Simarmata, H.A., Sianturi, H.C.J.A., Yudono, K. 2013. Measuring Vulnerability: Lesson from vulnerable groups along the example of Kampongs in North Jakarta. Proceedings of the Resilient Cities 2013 congress : Urban Resilience and Adaptation, 31 May-2 June 2013, Bonn, Germany.

13. Longhurst, R. (2010) - Semi-structured Interviews and Focus Groups. In: Clifford, N. J.; French, S.; Valentine, G. (eds.), Key methods in geography, pp.104-115, SAGE, London, Great Britain. ISBN: 978-1412935081.

14. World Atlas. 2017. Continents of the World by Degree of Urbanization. Article downloaded in https://www.worldatlas.com/articles/continents-ofthe-world-by-degree-of-urbanization-html

15. Wilhelm, M. 2010. Approaching Disaster Vulnerability in A Megacity: Community Resilience to Flooding in Two Kampungs in Jakarta. Doctoral Dissertation University of Passau, Achen. 2010

16. Setyaningsih, W et.al. 2015. Urban Heritage Towards Creative Based Tourism in the Urban Settlement of Kauman Surakarta. Procedia Journals of Social and Behavioral Sciences. Volumen 227. Page 642 - 649. 2016

17. World Bank. 1994. Enhancing the Quality of Life in Urban Indonesia: The Legacy of Kampung Improvement Program. Indonesia Impact Evaluation Report. 1994

18. Central Bureau of Statistics. 2015. Population data in Indonesia. 2015

19. Cutter, S. 2009. Social Vulnerability to Climate Variability Hazards: A Review of the Literature. Oxfam Report. University of South Carolina. 2007

20. Medan City Regional Disaster Management Agency. 2017. Medan City Disaster Flood Data. 2017

21. Katherina, et.al., 2017. Capacity of Urban Vulnerable People in Response of Environmental
Change and Floods. Research Center fo Population, LIPI.

22. Simarmata. H. 2015. How Informal Institutions Manage Flood-Risk at Community Level: An Empirical Study of Kampung Muara Baru Jakarta. Report of UNISDR. Page 30 - 45. Geneva. 2015

23. Moser. C and Satterthwaite. D. 2008. Towards Pro Poor Adaptation to Climate Change in the Urban Centers of Low and Middle - Incomr Countries. Human Settlements Discussion Paper Series. IIED. 2008

24. Burton, I., Kates, R.W., White, G.F., 1993. The Environment as Hazard, Second ed. Guilford, New York. 